\title{
Reconciliation: The Institutionalization of Memory in Post-Yugoslav Slovenia
}

\author{
Tjaša Konovšek
}

\author{
Institute of Contemporary History
}

\begin{abstract}
For Slovenian society the turning point in 1989 meant many things: the making of a new state, a transition to a new political and economic system, but also a new dimension of remembrance. The democratization process that started in the late 1980s and continued in the 1990s was deeply interwoven with the reconfiguration of public remembrance and the legitimation of the nascent Slovenian state. This resulted in a long and still ongoing project of reconciliation (sprava), a process of surpassing the divisions in society caused by the injustices and crimes committed by the Communist leadership in the previous decades. Its goal seems simple: to reach a point where history will no longer be a source of division in politics and where a relative unity could be established within the society.

As it moves away from the discussion of the disputed past itself, this article focuses on the history of the concept of reconciliation and the state's subsequent memorial policy of the last three decades. The development of the concept entails changes in the understanding of the past after two major political shifts: after 1990, when Slovenia became an independent state; and again after 2004, when it joined the European Union (EU). The identification of these shifts is based on the changes in the content of political and public debates. I propose that the Slovenian reconciliation between 1990 and 2004 be regarded as a specific element of the period from the end of communism until the Slovenian accession to the EU (transition), during which the political system changed.
\end{abstract}

\section{Keywords}

Transition; reconciliation; Slovenia; memory politics

\section{Asking the Questions}

The dividing line involved in the otherwise highly politicized concept of reconciliation in Slovenia is established by the interpretation of the pastmore accurately, by the question of fascism and Nazism along with the Slovenian collaboration; the question of the resistance of the partisan side and its relation to the Communist revolution; and the actions of both sides

\footnotetext{
* Tjaša Konovšek, Institute of Contemporary History, Privoz 11, 1000 Ljubljana, Slovenia; tjasa.konovsek@inz.si.
} 
during and after World War II with all their nuances. Thus, dealing with the concept of reconciliation, our understanding must be twofold: we should know what the concept entails, that is, understand World War II with all its broadness and complexities; and we must be familiar with the history of the concept itself-its forms, contexts, and uses throughout history until the present time. In the latter situation, we are faced with the question of memory, its institutionalization, as well as its public and political dimensions. Because reconciliation is a term used primarily in the political discourse of the past three decades, it directly affects the post-state's position regarding law making, memorials, and commemorations after it became an independent nation state in 1991.

In Slovenia during the 1990s, the conflict regarding the historical interpretation of World War II became so extreme that many public intellectuals, including historians, referred to it as a "cultural battle" (kulturni boj; Godeša 2016; Repe 2009; Rotar 1994). It is worth keeping in mind, however, that this perceived political polarization is mostly limited to political parties and political elites in general. This is one of the main reasons I will follow the somewhat rigid but useful typology of left- and right-leaning parties on the political spectrum. While parties sometimes shifted their views and accepted compromises in order to form useful alliances, the cleavage of the party references apropos the past remained surprisingly stable. Contrary to the political discourse, opinion research has shown a solid proportion of the Slovene population agreeing on the importance of values connected to the history of World War II, such as antifascism and solidarity (Toš et al. 2004, 16-27). While the past is not the only narrative to which the parties refer, it is one of the most expressive, displaying a strong resilience for political use through the decades (FinkHafner 2001, 177-80; Gašparič 2012, 108-23; Neumayer 2019, 28-40).

In the atmosphere of democratization and liberalization, historiography became an area of academic innovation. In Slovenia this meant building on the foundation of the Ljubljana school of the historiography of everyday life, history of ideas, mentalities, and social and cultural history, as well as opening itself up to new influences (Luthar 2017, 192). The academic revision of the history of World War II was required as well as carried out, adding complexity to the known topics and opening up some completely new aspects. Unfortunately, the positive momentum of rewriting, supplementing, and reexamining the history of World War II and subsequent years exhausted itself rather quickly. What was left was a politically motivated battle between two opposing views: the left-wing arguments based on the old Communist narrative and the right-wing version of history that, although relatively new at 
the time, structured its narrative along the same lines as the former Communist one, merely exchanging the negative and positive sides of history. If for decades any form of collaboration and struggle against the Communist revolution had been seen as reprehensible (and thus in need of forgetting), the newly emerged right-wing narrative completely rehabilitated the counterrevolution and collaboration, postulating it as the only possible and legitimate response to the threat of communism and other developments during World War II. What we are facing is an identical logic behind constructing the narrative where the "good" and "bad" guys switch places, depending on which of the two political perspectives is considered.

While only briefly touching on the original historical dispute involved in reconciliation (i.e., the post-World War II killings and the legitimacy of communism in what is today Slovenia), this article focuses on reconciliation's secondary function, the political use of the concept, and the making of the state's memorial policy. Judging the concept of reconciliation from the narratives that surround it, this topic might seem like an impossible quest to find any common ground between the historical factuality and its political use. My intention is the opposite: I argue that it is indeed possible to find a historical consensus about the crucial facts and establish foundations for critical historical research (Tucker 2008, 3-5); if it seems like it is not, then this is no longer a question of historiography and its methods but rather a matter of political interests, and, as such, a potential subject for academic research (Luthar 2017, 188). The main questions thus become What are the reasons for and circumstances of the popular and political belief that critical historical work is pointless, inherently flawed, and even hostile? When and by whom is this belief expressed? And for what purpose?

Apart from the chosen approach, there are other options of conducting analyses. Ideas similar to the Slovenian reconciliation are often described as transitional justice. The concept does partly belong to this category and was at times attempted to be executed as such in relation to the postwar killings (Elster 2004; Ricoeur 2004, 470-8; Simić and Volčič 2013). What the state was able to achieve in this context was to publicly acknowledge, institutionalize, and subsequently moralize as well as politicize the issue by shouldering the responsibility. The Slovenian state achieved that, though neither easily nor quickly.

Slovenia was not the only state in the process of the post-1989 transition that had to face (or avoid) its past (Neumayer 2019, 29-32; Tileagă 2018, 47-72). While the state of research on this topic from a historiographical point of view is still in its early stages, and neither a full symmetrical nor 
an asymmetrical comparison can be easily made, it is possible to draw some preliminary observations. In comparison with Czecho-Slovakia, where the lustration process (the purge of government officials) was second only to the example of Germany, a part of Slovenian politics attempted to initiate (and failed) a similar procedure, but only as late as eight years after the first democratic election had already taken place (Gjuričová and Zahradnícek 2018, 84-8, 96-100; Nedelsky 2004, 65-115; Wirsching 2012, 102-13). This delay suggests that Slovenia initially took a partially different path regarding its break with the past than some other states when transitioning from communism to liberal democracy. Reconciliation represented a vital element of this transition, mainly used precisely to gain the necessary political and popular unity in the moments when Slovenia was breaking away from Yugoslavia and seeking international support. Later on reconciliation became much more similar to the post-Communist ideals of Eastern and Central Europe, in terms of understanding and imagining the Communist past as well as the manners of facing it (Meyer 2008, 175). Nonetheless, because the topic of reconciliation and its political dimensions in Slovenia has practically not yet been explored, this is the first step that needs to be taken.

\section{Reconciliation before 1990}

In the Slovene political discourse of the past three decades, there was more than one wide-ranging controversy concerning the history that, for different reasons and in different ways, concerned the national community and acting politicians. Though questions such as the existence of the first Slovene nationstate (that, in a mythical and nationalistic manner, is sometimes recognized as beginning in the early Middle Ages principality of Carantania), merited some political and nation-building potential, none has been as frequently and as successfully used as the idea of reconciliation.

The original discord, echoed in the modern-day reconciliation, stems from the division between the atrocities committed by the partisan resistance (the Communist elimination of political opponents during World War II and the clandestine killings at the end of the war) and the collaboration units (the center-right part of Slovenian politics, the leadership of the Catholic Church, and part of the civil population). Although the context of total war meant extraordinary circumstances, it remains a fact that the resistance movement in Slovenia, almost exclusively led by the Communists beginning in 1943, committed a number of transgressions, including the postwar massacres in 1945 of some of the repatriated Yugoslav collaboration units who unsuccessfully tried to surrender to British forces rather than fall under the 
control of the Yugoslav partisan movement. This event is more commonly known as the Bleiburg repatriations or the Bleiburg tragedy, especially in Croatia. In Slovenia the massacres are sometimes referred to as the Vetrinje tragedy, but this name already bears a heavy political (right-wing) and ideological (Church-supported) connotation. The term povojni poboji (postwar killings or postwar massacres), on the other hand, serves as the most neutral description of the events, and it is the most common expression for this historical event in the Slovene public. From this point of view, a comparison of Slovene memory institutionalization in regard to the massacres with other Yugoslav states could bring further clarity on the matter, but because I analyze reconciliation as a concept that was a vital part of the political transition after 1989, it is impossible to ignore the different historical trajectories of Slovenia versus other post-Yugoslav nation-states that experienced years of war as well as ethnic cleansing in the 1990s.

The postwar regime depended heavily on the legacy of the antifascist and Communist liberation movement; however, these mistakes were not adequately addressed for decades (Corsellis and Ferrar 2015; Lowe 2012; Ramet 2009). For example, the number and structure of the casualties of war itself, the wartime revolution, and other war-related reasons were long speculated about and often tilted in favor of the partisan liberation movement. In the context of 20th-century political changes, the Institute of Contemporary History in Ljubljana initiated a thorough long-term research project, partially financed by the state. A group of professional historians were tasked with determining the number of fatalities during and in connection with World War II. Whenever possible the researchers noted the casualties' basic information, including the cause of death. The research determined that out of 99,911 people identified thus far, $6.7 \%$ were victims of postwar killings (Institute of Contemporary History 2020).

Determining the exact number and names of those killed failed to reduce the political tension and revisionist tendencies. This, along with the historical view of the development of the reconciliation debate itself, is one of the indicators of the transformations of the concept. Reconciliation and postwar killings were not always so very interdependent. In fact, the idea itself is older than implied by its modern exclusive reduction to the postwar killings. The first appeal for reconciliation was made on May 1, 1945, a few months before the postwar killings. It was issued by the collaborating Slovenian politicians, organized in the self-proclaimed National Board for Slovenia (Narodni odbor za Slovenijo), asking the partisans to set aside their fight against the collaboration army (the Home Guard, or domobranci) and unite for the good of the entire nation 
(Repe 1988, 169). When it became clear that the Allied victory was imminent, the board attempted to shift its allegiance publicly and seek favor with the victorious side. Their appeal had no effect; it failed to stop the fighting or convince the general public of the relativity of their collaboration (Cmrečnjak 2016, 384-8). Reconciliation was soon echoed by the Slovenian Catholic Church, which stated its loyalty to the new regime and excused itself from its open collaboration during the war. The idea of reconciliation vanished from the public discourse for a few decades and remained an active topic only among the Slovenian emigration community, that is, those who collaborated in different ways and degrees with the occupying forces during the war, those who were expelled from Yugoslavia after the war for political, ideological, or other reasons, and those who left the state by their own accord (Cmrečnjak 2016, 385-6; Dolinar 1998, 17).

The public debate about reconciliation reemerged in Slovenia in the 1970s. Edvard Kocbek, a prominent public figure and a former partisan fighter, spoke openly about the postwar killings in an interview for a Trieste-based newspaper in 1975. He departed from the official Communist line a few years earlier and, as one of the consequences, decided to shoulder his part of the responsibility and publicly admit his circumstantial guilt regarding the crimes committed by the partisans during and after the war (Fischer 2005, 111727; Inkret 2011, 501-59; Pahor 1975, 1989, 388-403). Apart from bringing the public's attention to the postwar killings, he added an essential element to the understanding of reconciliation itself. For Kocbek, reconciliation not only was meant as a process initiated by and addressing the elites (the Church, Communists, active politicians, intellectuals, etc.) but was also seen as a matter of the collective responsibility of the entire nation. The regime reacted harshly to Kocbek's testimony and used it as the ultimate chance to discredit him and distance itself from any form of reconciliation (Gabrič 2019, 193-220; Kocbek 2004, 80). A few years later, Spomenka Hribar reintroduced reconciliation into the public debate. Like Kocbek, Hribar, an influential public intellectual and well-known regime critic, wrote an article for a volume dedicated to Kocbek, titled "Krivda in greh" ("Guilt and Sin"). She reinforced the idea of a nation as a living entity, wounded by the civil war, which needs to heal collectively in order to move toward a successful, tolerant, and democratic future (Hribar 1987b, 10-68).

Hribar and other coauthors of the volume waited three years for it to be published (1984-7). Shortly after reaching the public, the flip side of her proposed idea of reconciliation emerged. The emerging right-wing parties, forming among the civil opposition of the late 1980s, used her idea to 
consolidate their political agenda and use the momentum of the now public knowledge of the Communist crimes to delegitimize the regime and its past. Shortly after "Guilt and Sin" finally came out, Hribar published another article in the special 57th edition of the critical Nova revija magazine, in which she warned the public about misunderstanding her recently launched idea (Hribar 1987a, 74-103). Reconciliation, she argued, did not mean the forced unity and uniformity of the society that the emerging right-wing parties were after. That, in her opinion, could only lead to further hatred and chauvinism, let alone the drastic politically motivated revision of the past.

Following the development of Hribar's activities and initiatives, the reconciliation project culminated in 1990 as one of the crucial elements of the Slovenian independence process. Under the influence of Hribar, Milan Kučan, the president of the Presidency of SR Slovenia, who later became the first democratically elected president of the Republic of Slovenia, and Metropolitan Archbishop Alojzij Šuštar attended a joint reconciliation ceremony in the Kočevski Rog forest, one of the most notorious postwar killing sites, on July 8. Around 30,000 people attended the ceremony, which was broadcast live on television. The public debate that surrounded the event was extremely lively. Both the political actors and the public took the ceremony as a oncein-a-lifetime event that bridged the ongoing argument between the state and the church, canonizing itself as one of the crucial elements of the Slovenian transition (Godeša 2016, 102-6; Repe 2002, 127; Slabe 2006, 14).

The National Assembly election in April 1990 played a decisive role in the state's changing relationship with the past. After the election the assembly became the center of political debates and decision-making, where numerous discussions about the past were also held. A profound shift in the way of viewing the past as well as the present was mirrored in the opening speech by France Bučar, the president of the newly elected assembly, on May 9, 1990. At its constitutive meeting, he marked the election of that year and the consequent convening of the democratic Slovenian National Assembly as "the end of the civil war that was tearing us apart and paralysing us for nearly half a century," a realization that, according to Bučar, "forces us into national reconciliation," which means "not only pacification, but also an acknowledgement of the good intentions of your former enemy, recognition of their morality, and worthiness of rehabilitation" (Slovenian National Assembly 1990). Through the Kočevski Rog ceremony and the 1990 election (a strong national note notwithstanding), reconciliation reached the central state institutions and transformed itself from a civil to a political project. 
As such, it profoundly affected the state's memorial policy, as well as public remembrance and its general understanding of the past.

\section{From an Internal Dilemma to an Externalized Memory Policy}

With the process of democratization and liberalization between 1989 and 1992, the state took upon itself the symbolic and functional responsibility for reconciliation. As of the first democratic election of April 1990, the assembly became the central stage for political debates, which makes its records a valuable source for examining the political application and understanding of reconciliation (Gašparič 2012, 40-1). By analyzing the extensive corpus of parliamentary records (including its working bodies) thanks to the advancements in digital records, it is possible to detect when reconciliation was an especially prominent topic and, subsequently, when the institutionalization of memory was most intense. In the parliamentary records of the past 30 years, three of them stand out: 1997, 2009, and 2015. (In 1997 reconciliation was mentioned 121 times; in 2009, 153 times; and in 2015, 262 times. The average number of mentions per year between 1990 and 2018 was 48 times [Clarin 2020].) Because the aim of this article is not quantitative research, these deviating years are used only as rough markers to point out the intensity of the parliamentary debate and indicate the specific issues that the members of parliament discussed when mentioning reconciliation.

In 1997 reconciliation was mainly used when discussing national holidays (Parliamentary Gazette 1997a), the resolution on the illegality of the Communist regime (Parliamentary Gazette 1997b), and a law to correct its crimes (Parliamentary Gazette 1997c). The debate about a somewhat changed declaration on the illegality of the Communist regime continued in early 1997 (Parliamentary Gazette 1997d). All of these proposals were introduced by the right-wing opposition and eventually rejected. Still, they prompted a lively debate about the memorial politics and the state's attitude to the past. They exposed the polarity of the left- and right-wing history narratives as well as their shared black-and-white tendencies. To bridge the dividing gap between the political parties at the time, parliament organized a public debate on reconciliation in 1998 and 1999, titled "Attitude to the Past and National Reconciliation: Acknowledging Different Views as an Act for the Future of the Republic of Slovenia" (Parliament of the Republic of Slovenia 1998), hoping that speaking openly about reconciliation and confronting as many different views as possible would exhaust the ever-intensifying political charge of the past. This was not the first time that parliament attempted to overcome the political division regarding past events with the help of external 
experts and members of civil society. In 1995 parliament tasked the Institute of Contemporary History (in cooperation with other leading historians in the field) with providing a report on the Slovenian political history from 1929 to 1955 . The report was completed in September of that year but was neither discussed nor in any other way applied in parliamentary work (Čepič 1995). Similarly, the 1998 and 1999 public debate on the past did little to appease the political parties' divisions or change the public's opinion of the past.

About a decade later, in 2009, reconciliation was once again a popular parliamentary topic, mainly due to the European Parliament resolution of April 2, 2009, on European conscience and totalitarianism (European Parliament 2009). After many heated debates, the Slovenian Parliament answered the European initiative with a brief statement, revealing an almost nonexisting consensus among the members of parliament. Issued in October 2009, the statement declared that members had familiarized themselves with the European Parliament resolution, then listed what Slovenia had already done to achieve the goals set in the original resolution (Legal Information System 2009). However, for the public, the European Parliament resolution was not the most stirring event related to reconciliation. By 2009 the discussion about the past had been replenished by a series of new postwar killing site discoveries, focusing the debate on the victims of the partisan transgressions rather than on the (dis)continuity of the previous regime. In that year a new killing site called Huda Jama was discovered near Laško, drawing the media attention to the newly discovered human remains and, consequently, to the postwar killings (Multimedia Center of the Slovenian National Television 2015). While Huda Jama was an example that particularly stirred up the public, it was merely one of many such discoveries during the past decade. In 2001 the first well-publicized site was discovered in Zgornja Bistrica. Both of these and many others have been discovered as a part of the state's project of mapping the locations of the mass graves, which gained a basic legal background and state funding in 2000 (Ferenc 2004, 125-41; 2012; Juhart and Z̈alec 2012), with additional legal backing in 2003 (Registry Act and War Cemeteries Act; Official Gazette of the Republic of Slovenia 2003a,b). Some killing site locations were generally known to the public, and the project aimed to specify them and establish their scope.

Discoveries such as these created increasing public pressure on the state to mark and manage the newly discovered killing sites. Before the mass grave in Zgornja Bistrica was excavated, the state had not had any systemic procedures in place to respond to such findings. By not marking the graves or managing the sites that were becoming increasingly important in terms of 
public opinion and from the point of view of any organized memorial, the state left the initiative to church-related organizations. The most prominent example of this is the New Slovenian Testimony (Nova slovenska zaveza) civil initiative, which has led the project of setting up parish memorial plaques since 1995. By colonizing the rural memorial landscape with its own narrative of reconciliation, revisionism, and nationalism, this initiative was gaining the upper hand in instrumentalizing the topic of postwar killings (Luthar and Luthar 2003, 647). The state needed to externalize its relation to the past by contributing to the memorial landscape. The first state-sponsored monument, Memorial Park (Park spomina), was built in 2004, eleven years after the project had been first announced, at a site in Teharje. While this delay might suggest the state's passivity, the overview of law making and the content of the parliamentary debate reveals a number of dilemmas that its members had to face when dealing with questions about the past. This was much more of a stalemate situation than an example of inactivity (Gašparič 2012, 91).

The state's tendency to externalize and memorialize the past continued and reached its peak between 2015 and 2017, when the construction of the central national memorial dedicated to reconciliation began. The project was initiated soon after the 2009 discovery of the Huda Jama mass grave. A year later Spomenka Hribar became the head of the project group, founded with the Ministry of Labor, Family, Social Affairs, and Equal Opportunities, that led the project until 2017, when the monument was formally unveiled. Though it was first proposed to form a part of Ljubljana's Žale Central Cemetery, the project group relocated the monument to Ljubljana's central Congress Square. Besides the monument's location, its name was highly disputed. Titled the Monument to the Victims of All Wars (and War-related Casualties in the Territory of the Republic of Slovenia), it embodies the equalization between communism, Nazism, and fascism, as well as between their supporters and victims. Composed of two massive concrete blocks, it suggests the disunity of the Slovenian nation: divided in the present but, unseen and unnoticed, stemming from the same ground. As such, it epitomizes the seemingly eternal division rather than encourages a calm or fruitful reflection on the past (Zajc 2020, 161-5; Žerovc 2020, 172-87).

If in the 1990s the Slovenian Parliament's main focus was state building, ensuring a break with the former regime, and moving toward Europe (changing laws and public holidays, holding open debates), the policies after the completed transition involved intense discovering, documenting, and marking the postwar killing sites-taking an active part not in ensuring an environment conducive to professional historical research and cultivating 
respect for its results, but instead revising the past for its own political gains. In the 1990s Slovenia at least partly understood itself as a bearer of the positive Communist legacy (e.g., the case of Slovenian economic transformation; Christiaens, Mark and Faradlo, 2017; Crowley and Stanojević 2011). However, after joining the European Union and electing its first right-wing government under the leadership of Janez Janša's Slovenian Democratic Party (Slovenska demokratska stranka) in 2004, the balance of the left- and right-wing understanding of the past, already firmly divided, tilted heavily toward the right. The critics of the state-sponsored memorials, mostly comprised of left and center-left political parties as well as some publicly recognized intellectuals, often remark on the Slovenian state's retrospective identification with the post-Communist European countries by equating the former Slovenian (and Yugoslav) communism with the Communist regimes of Eastern and Central Europe, ignoring the historical differences (such as Tito's break with Stalin and the delegation system of 1974), orientalizing communism and proclaiming it as a mistaken chapter of Slovenia's past.

\section{Tracing Changes in Parliamentary Debates}

Taking into account the state-sponsored mapping of the killing sites and state-funded investigative commissions along with the state's regulation of the commemoration sites, the shift from internal political discussions and finetuning of the discontinuity with the Communist regime toward an external engagement with the past becomes apparent. As Oto Luthar writes, "The first to learn this were the new conservative political elites, which discovered that the quickest way to win the electoral majority was to play the dominant nationality's latent resentment and fear of difference and otherness" (Luthar 2017, 189-91).

The election results of 1992, 1996, and 2000 repeatedly-with a six-month exception in 2000-brought to power center-left governments, dominated by the Liberal Democracy of Slovenia (Liberalna demokracija slovenije), leaving the major right-wing parties in the permanent role of the opposition. In 1997 the largest opposition member-the Slovenian Democratic Party and its leader, Janez Janša - would often address the political power of the Liberal Democratic Party through the idea of a threat of the continuity of the Communist regime, insinuating its illegitimacy to lead the government during the Slovenian transformation into an EU member state. In the minds of the right-wing parties, Europe was synonymous with civilization and Christianity. How, then, could Slovenia successfully join the EU led by 
a political elite that, for them, personified what remained of communism (Konovšek 2020, 178-85; Slovenian National Assembly 1997a)?

It was within this atmosphere that in May 1997, the Slovenian Democratic Party first proposed a change regarding national holidays. Assessing the situation at the time, the proposers concluded that one of the former regime's central holidays, the Liberation Front Day (April 27, the day when the resistance against the German and Italian occupiers began in 1941) was, in fact, based on a lie. Not only was the Liberation Front established a day earlier, but the organisation was (as verified by historians) initially called the Anti-Imperialist Front (Protiimperialistična fronta) and, for a brief period in 1941, took upon itself to fight any imperialist force. Only after the German invasion of Russia was the organization renamed and it started a full-scale attack against the occupying forces of Nazi Germany and fascist Italy. By underlining these "facts that have been covered up for decades" (Parliamentary Gazette 1997a), the proposers of the new holiday questioned how Slovenia could ever join the EU when one of its major national holidays was based on an anticapitalist notion. Instead, the first signatory of the proposal, Janez Janša, suggested that the holiday be abolished. Instead, the day symbolizing the true national resistance of Slovenia should be June 26, as it was on that day in 1991 that the "Slovenian nation resisted the occupying Yugoslav Army" (Slovenian National Assembly 1997b). Thus, Janša turned the tables: instead of the World War II occupiers, the aggressor was now the Communist regime; and the focus of unity was shifted to the state-forming national context of 1991. The proposal recontextualized communism as a foreign, Soviet ideology, forced on Slovenia. Other members of parliament reacted resolutely, either supporting the search for the truth in the past or contradicting this view by insisting that the antifascist struggle of World War II should stay a positive value in Slovenian society.

Similar arguments were repeated during the discussion of December 1997. The resolution on the illegality of the Communist regime coupled with a proposed law to correct the alleged injustices, sponsored by Alojz Peterle (Slovenian Christian Democrats) and Janez Janša, stated that by gaining power, the Communist regime forced citizens to live in a state characterized by lies and crime, violating their rights while favoring those who had previously committed mass murder (alluding to the revolutionary violence). Peterle and Janša suggested that parliament should find the Communist Party responsible for separating Slovenians from European civilization, for the unaccounted murders, collectivization of property, and misuse of state institutions (including schools) to further its own agenda, as well as for 
imposing on them an ineffective economic system. Rendering the entire Communist regime illegitimate, the authors of the proposed resolution held the leadership of the Communist Party of Slovenia fully responsible for all the listed crimes and worthy of contempt. Those individuals who had been marked as collaborators and enemies of the state should, with this resolution, gain moral satisfaction, honor, and the right to be remembered. In this, we can once again see the polarized nature of the political imaginary: in the proposed resolution, everybody who had once been a foe was now a friend and vice versa (Parliamentary Gazette 1997b,c).

The fact that at the time this resolution was proposed, the Communist Party had not been in existence for nearly a decade was not a problem for its submitters. In fact, Janez Janša claimed that the monopolization of power that the Communists had achieved during World War II had persisted throughout the changes of the 1980s and 1990s. According to him, the Communists still ruled the country in the late 1990s, masked only by those foolish enough to be tricked into an apparent coalition (Slovenian National Assembly 1997c). This was only one of the pieces in the emerging political conspiracy theory, promoted by the Slovenian Democratic Party and other right-wing sympathizers, stating that the Communist secret police and the Communist elite (the so-called udbomafija) were still in power in Slovenia (Hribar 1996, 20-6; Tucker 2008, 12).

After Slovenia had successfully joined the EU, the former right-wing opposition took charge. The discussions about the past in parliament changed. To discover the truth about both the past and the present was repeatedly stated as a prerequisite for a peaceful future and a reconciled nation. The saying "Tell me what you think of the past, and I will tell you what you want from the present and future" was seemingly reverberating among the members of parliament regardless of their party affiliation (Slovenian National Assembly 1997c). The reconciliation was no longer an issue by itself. Instead, one of its formerly less-prominent aspects now became the focus of attention: the postwar killings and the mass graves. The debate that had been limited to parliament's plenary sessions in the 1990s now moved to its working bodies. Consequently, the Commission for Petitions, Human Rights, and Equal Opportunities (Komisija za peticije ter ćlovekove pravice in enake možnosti) became one of the centers of the reconciliation discussions. It took upon itself to create equality and observe the rights of the state's current citizens and, just as importantly, those of the dead.

After 2004 the commission was led by Eva Irgl, a member of the Slovenian Democratic Party. Unlike those who had taken part in the original 
reconciliation debate in the 1990s, Irgl started her political career in 2004 and can thus be viewed as a member of the new generation of politicians. This contributed to the change in the language used to describe the issues related to postwar killings. The arguments, often employed in the late $1980 \mathrm{~s}$ and 1990s, called for much less power regarding the shocking findings of the killing sites. Because of the scope and severity of the findings, they became a point of an apparent agreement between politicians, regardless of their party affiliations. Following the logic of human rights, they unanimously condemned violence and demanded piety. The Communist regime that had enabled such crimes was reduced almost solely to the component of evil. The pendulum of the political power and moral high ground swung toward the right, and only a few politicians contradicted this prevailing view (Slovenian National Assembly 2009a).

If Europe influenced the political imagination and discourse as the civilized world to which Slovenia aspired, it also had a practical effect on the formation of the Slovenian legislation. One such initiative came in the form of the European Parliament resolution of April 2, 2009, on European conscience and totalitarianism (European Parliament 2009). In Slovenia the question of how to respond to it was first heavily debated by the parliamentary Board for Domestic Policy, Public Administration, and Justice (Odbor za notranjo politiko, javno upravo in pravosodje). The political meanings and suggestions attached to the Communist past-such as equating its totalitarian component with fascism and Nazism-exposed the ongoing progress of its delegitimization. The repeated arguments that the truth about the past had surfaced in the form of the newly discovered killing sites during the past few decades would usually be followed by suggestions of state-related actions with revisionist tendencies (Slovenian National Assembly 2009b). Comparing the Slovenian Parliament's final response to the European Parliament resolution and the ferocity of the debate that had preceded it, the response seems short and relatively evasive. First, it states that the Slovenian state is neither capable nor authorized to pass any judgment on the past; second, it refers to the events and atmosphere of the late 1980s and 1990s, structured around Slovenian independence, where civil society and the state first needed to deal with the issues at hand (Legal Information System of the Republic of Slovenia 2009). This period, it seems, remained a reference point of relative unity and consensus in the minds of the members of parliament until 2009.

By then the revisionist political tendencies were heavily supported by the Study Center for National Reconciliation in Ljubljana. Established in 2008 by the government of Janez Janša, the center's purpose was to study 
the violation of rights by the totalitarian regimes in the Slovenian territory in the 20th century, thus establishing the foundations for the correction of injustices and creating possibilities for harmonious civilizational and cultural development (Legal Information System of the Republic of Slovenia 2008). It remained unclear, however, how the center (or the state) should achieve this. It is telling that the majority of the center's activities were (and still are) dedicated not to reconciliation as such, but to the Communist revolution and totalitarianism, victimhood, the untold truth of the past, as well as to memory and education. This includes publishing, recording testimonies of those who were affected by the socialist system, and collecting other primary sources (Study Center for National Reconciliation n.d.). Other institutions, such as universities (University of Ljubljana, University of Maribor, and others) and research centers (Institute for Contemporary History, Research Center of the Slovenian Academy of Sciences and Arts, and the Academy of Sciences and Arts itself) provided no explicit response. Their members or representatives sometimes publicly contradict the center's findings or activities, but perhaps most telling is the fact that the center's production thus far has had no serious impact on academic study. It seems that the main area of activity is the public sphere: exposing ideas to the media, organizing events, and publishing.

Its creation is similar to the dilemmas of other Eastern and Central European states: to what degree and in what way should the state control the development of historiography and, subsequently, the understanding and interpretation of the past? In the case of Slovenia, expert historians have judged the center as revisionist and partly unprofessional (Luthar 2017, 191-3). Nevertheless, its influence and public presence have not diminished over the years, though the personal and professional connections between the center and Janša's Slovenian Democratic Party are well known. Andreja Valič Zver, who was a director of the center since its creation until 2020, was, at the same time, also a member of the party and its executive board, as well as a close personal friend of Janša and a wife of the Milan Zver, the minister of education at the time of the center's establishment. These were the main controversies that evoked a response in Slovene political circles and the broader public (Dnevnik 2020; Mladina 2021).

Another notable difference between the 1990s and the time after 2004 is the inclusion of the members of civil society and professional historians in the discussion. While in the 1990s both historians and representatives of civil organizations would frequently be consulted, the right-wing policy in the period after 2004 mostly ignored the established professions and instead developed new institutions in accordance with their own political agenda (e.g., 
the Study Center for National Reconciliation). The educational component of the state's memorial policy represents another area of potential research, and it seems to confirm the same 2004 turning point as the analysis of parliamentary records. As some historians have already noted, the changes that took place in 1990 introduced clear nationalization implications into history textbooks, while the turning point of 2004 subsequently resulted in a thorough reform of the history curricula. Besides announcing the government's plan to further strengthen the national view of the past, Milan Zver, the minister of Education, characterized the teaching of history as "overly communist," ignoring, in the process, the findings of academic historiography (Vodopivec 2009, 64-5). Perhaps nothing emphasizes the need for further research into the state's memorial policy than statements such as this.

After years of discovering killing sites and the shift in the politically motivated revision of the past, the past decade has gradually shown the results of reconciliation. Neither society nor politics have reached a desired consensus about the past. Perhaps more importantly, the apparent absolute need to reach it is no longer questioned-by politicians, civil society representatives, or the media. The current relationship with the past is perhaps best illustrated by the Slovenian National Television's airing of a documentary titled Razdvojeni (Divided) in the summer of 2020, depicting the onset of the Slovenian ideological break during World War II (Multimedia Centre of the Slovenian National Television 2020a). The film was followed by an hour-and-a-halflong discussion, in which four historians discussed the topic of the Slovenian ideological division and reconciliation. Setting aside the historiographical quality, professionalism, and content of the discussion participants, the choice of guests itself clearly reflected what has become a canonized public attitude when dealing with the past: presenting two pairs of historianstwo seemingly equal but incompatible parts - unable to reach any common understanding (Multimedia Centre of the Slovenian National Television 2020b; Zelizer 2008, 379-87). This, too, reveals the extent of the changed image of the externalized division that, in turn, calls for reconciliation. It is, in short, the media-created vision equivalent to the two immobile blocks of the Monument to the Victims of All Wars.

\section{Conclusion}

An analysis of the development of the parliamentary discussions and the state's turning points in its relationship with the past reveals that reconciliation has never been a static concept. Apart from having specific characteristics before the 1990s, the concept, along with the state's memorial policy, underwent 
a significant change after 1990 and once again after 2004. This article has shown that reconciliation has been used first as an elitist concept, meaning it had no grassroots initiative but rather was launched by a small group of intellectuals who wanted to seize the historical moment connected to the changes of 1989 and reach a long-lasting political consensus regarding the events of World War II and the socialist system that followed. While in the early 1990s, all of the political parties at least in some way acknowledged the historical facts, presented by various historians, it was the right-wing parties, mostly Janez Janša’s Slovenian Democratic Party and Alojz Peterle’s Christian Democrats that reheated the reconciliation debate in the late 1990s. By doing this, they attempted to shift political power from the ruling Liberal Democracy of Slovenia, which took every election from 1992 until 2000 by a landslide. The debate about the past and the changes needed to ensure reconciliation was an issue of the parliamentary coalition and opposition and thus primarily internal. For the most part, the state's relationship with the past was a question of making a sufficient break with it in the hopes of gaining political power and leading the state toward the EU in accordance with the prevailing political interests.

Both the public and politicians were shaken by the findings of mass graves in the early part of this century. This, alongside the shift in government (Janša's first term in office was from 2004 and 2008) and with Slovenia's successful admission into the European Union in 2004, brought changes to the intensity and nature of the state's attitude toward the past. Resolute intentions to revise the past and establish a firm state-backed memorial policy became entirely obvious. The new coalition, led by the Slovenian Democratic Party, announced a general change in policy. It showed a significant increase in the state's interest in matters of national importance. In terms of the memorial policy, this was reflected in the erection of state-sponsored memorials and the systematic mapping and arranging of mass grave sites. In terms of reconciliation and parliamentary discussions, it implied the affirmation of the alternative populist historical narrative that, as shown above, was as absolute in its perspective as that of the former Communist regime. It is for this reason that reconciliation should be further researched as a form of political tactic and discourse of the past three decades, alongside further complex and innovative research of the history of World War II. 


\section{Journal of Nationalism, Memory \& Language Politics 15(1)}

\section{References}

Čepič, Zdenko. 1995. Ključne značilnosti slovenske politike v letih 1929-1955. Znanstveno porocilo [The key characteristics of Slovenian politics between 1929 and 1955: A scientific report]. Ljubljana, Slovenia: Inštitut za novejšo zgodovino.

Christiaens, Kim, James Mark, and José M. Faradlo. 2017. "Entangled Transitions: Eastern and Southern European Convergence or Alternative Europes? 1960s-2000s." Contemporary European History 26 (4): 577-99.

Clarin. 2020. "Common Language Resources and Technology Infrastructure, Slovenia." Accessed November 11, 2020. http://www.clarin.si/info/about/.

Cmrečnjak, Sašo. 2016. “Slovenska sprava: zgodovinski pregled” [Slovenian reconciliation: A historical overview]. Historical Review 70 (3-4): 382-436.

Corsellis, John, and Marcus Ferrar. 2015. Slovenia 1945: Memories of Death and Survival after World War II. London and New York: I. B. Tauris.

Crowley, Stephen, and Miroslav Stanojević. 2011. "Varieties of Capitalism, Power Resources, and Historical Legacies: Explaining the Slovenian Exception." Politics and Society 39 (2): 268-95.

Dnevnik, 2020. Andreja Valič Zver odstopila kot direktorica Študijskega centra za narodno spravo. [Andreja Valič Zver resigned as director of the Study Center for National Reconciliation]. Accessed May 12, 2021. https://www.dnevnik.si/1042940120.

Dolinar, Franc, ed. 1998. Resnici na ljubo: izjave ljubljanskih škofov o medvojnih dogodkih [For the sake of truth: The statements of Ljubljana's bishops about the wartime events]. Ljubljana, Slovenia: Družina.

Elster, Jon. 2004. Closing the Books: Transitional Justice in Historical Perspective. Cambridge: Cambridge University Press.

European Parliament. 2009. "European Parliament Resolution of 2 April 2009 on European Conscience and Totalitarianism." Accessed November 9, 2020. https:// www.europarl.europa.eu/sides/getDoc.do?pubRef=-//EP//TEXT+TA+P6-TA-20090213+0+DOC+XML+V0//EN.

Ferenc, Mitja. 2004. "Kako do evidence prikritih grobišč v Republiki Sloveniji?” [How to access the records of hidden graves in the Republic of Slovenia]. Contributions to Contemporary History 44 (1): 125-41.

-_— 2012. Prekop žrtev iz prikritih grobišč (1991-2011) [Re-burying the victims from the hidden graves (1991-2011)]. Ljubljana, Slovenia: Znanstvena založba Filozofske fakultete.

Fink-Hafner, Danica. 2001. Politične stranke [Political parties]. Ljubljana, Slovenia: Fakulteta za družbene vede.

Fischer, Jasna, ed. 2005. Slovenska novejša zgodovina: od programa Zedinjena Slovenija do mednarodnega priznanja Republike Slovenija 1848-1992 [Slovenian contemporary history: From the United Slovenia Program to the International Recognition of the Republic of Slovenia, 1848-1992]. Ljubljana, Slovenia: Mladinska knjiga.

Gabrič, Aleš. 2019. V senci politike. Opozicija komunistični oblasti v Sloveniji po letu 1945 [In the shadow of politics: The opposition to the Communist rule in Slovenia after 1945]. Ljubljana, Slovenia: Cankarjeva založba. 
Gašparič, Jure. 2012. Državni zbor 1992-2012. O slovenskem parlamentarizmu [The National Assembly, 1992-2012: On Slovenian parliamentarism]. Ljubljana, Slovenia: Inštitut za novejšo zgodovino.

Gjuričvá, Adéla, and Tomáš Zahradníček. 2018. Návrat parlamentu. Češi a Slováci ve Federálni m shromáz dèni 1989-1992 [The return of the parliament: Czechs and Slovaks in the Federal Assembly, 1989-1992]. Prague: Argo.

Godeša, Bojan. 2016. "Reconciliation Instead of History." Contributions to Contemporary History 56 (3): 101-7.

Hribar, Spomenka. 1987a. "Avantgardno sovraštvo in sprava" [The avant-garde hatred and reconciliation]. Nova revija: mesečnik za kulturo 57 (6): 74-103.

1987b. "Krivda in greh." [Guilt and sin]. In Kocbekov zbornik [Kocbek's volume], edited by Dimitrij Rupel, 10-68. Maribor, Slovenia: Obzorja.

1996. “'Udbomafija' kot strukturni element današnje desne ideologije” [“Udbomafia” as a structural element of today's right-wing ideology]. Družboslovne razprave 12 (21): 20-6.

Inkret, Andrej. 2011. In stoletje bo zardelo: Kocbek, življenje in delo [And the century will blush: Kocbek, his life and work]. Ljubljana, Slovenia: Modrijan.

Institute of Contemporary History. 2020. "World War Two Casualties.” Accessed November 11, 2020. https://www.sistory.si/zrtve/historiat.

Juhart, Janez, and Bojan Žalec, eds. 2012. Reconciliation: The Way of Healing and Growth. Zürich and Münster: Lit.

Kocbek, Edvard. 2004. Dnevnik: izbor iz dnevnika od 1954 do 1977 [Diary: Selection from the diary from 1954 to 1997]. Ljubljana, Slovenia: Cankarjeva založba.

Konovšek, Tjaša. 2020. "Prekletstvo številke 45: konstituiranje slovenskega državnega zbora in vlade v letih 1996-1997" [The curse of number 45: The formation of the Slovenian National Assembly and the government between 1996 and 1997]. Contributions to Contemporary History 60 (2): 168-89.

Legal Information System of the Republic of Slovenia. 2008. "Decision on the Establishment of the Public Institution Study Center for National Reconciliation." Accessed November 12, 2020. http://www.pisrs.si/Pis.web/pregledPredpisa?id=SKLE7554.

_- _ 2009. "Declaration on Acquaintance with the European Parliament Resolution on European Consciousness and Totalitarianism of 2 April 2009." Accessed November 9, 2020. http://www.pisrs.si/Pis.web/pregledPredpisa?id=DEKL27.

Lowe, Keith. 2012. Savage Continent: Europe in the Aftermath of World War II. London: Viking.

Luthar, Breda, and Oto Luthar. 2003. "Kolonizacija spomina. Politika in kontekstualnost domobranskih spomenikov po letu 1991" [The colonization of memory: Policy and contextuality of Home Guard memorials after 1991]. In Zbornik Janka Pleterskega. [Janko Pleterski's volume], edited by Oto Luthar and Jurij Perovšek, 647-63. Ljubljana, Slovenia: Založba ZRC.

Luthar, Oto. 2017. "Post-Socialist Historiography between Democratization and New Exclusivist Politics of History." In Of Red Dragons and Evil Spirits: Post-Communist Historiogra- 


\section{Journal of Nationalism, Memory \& Language Politics 15(1)}

phy between Democratization and New Politics of History, edited by Oto Luthar, 187-207. Budapest and New York: CEU Press.

Meyer, Erik. 2008. "Memory and Politics." In Media and Cultural Memory, edited by Astrid Erll and Ansgar Nünning, 173-80. Berlin and New York: Walter de Gruyter.

Mladina. 2013. Zverova žena. [Zver's wife]. Accessed May 12, 2021. https://www.mladina. si/141623/zverova-zena/.

Multimedia Center of the Slovenian National Television. 2015. "Huda jama je bila prehuda, po državi še vedno stotine neoznačenih grobišč” [Huda Jama was too hard, hundreds of unmarked graves still across the country]. Accessed November 14, 2020. https://www. rtvslo.si/slovenija/huda-jama-je-bila-prehuda-po-drzavi-se-vedno-stotine-neoznacenihgrobisc/359553.

2020a. "Razdvojeni" [Divided]. Accessed November 14, 2020. https://4d.rtvslo.si/ arhiv/dosje/174698892.

2020b. "Razdvojeni-pogovor" [Divided-Conversation]. Accessed November 14, 2020. https://www.rtvslo.si/4d/arhiv/174699214?s=tv.

Nedelsky, Nadya. 2004. "Divergent Responses to a Common Past: Transitional Justice in the Czech Republic and Slovakia." Theory and Society 33 (1): 65-115.

Neumayer, Laure. 2019. The Criminalisation of Communism in the European Political Space after the Cold War. London and New York: Routledge.

Official Gazette of the Republic of Slovenia. 2003a. "Registry Act." April 18.

2003b. “War Cemeteries Act." July 4.

Pahor, Boris. 1975. Edvard Kocbek: pričevalec našega časa [Edvard Kocbek: The witness of our time]. Trieste, Italy: Zaliv.

1989. Ta ocean, strašno odprt: dnevniški zapisi od julija 1974 do februarja 1976. [This ocean, terribly open: Diary entries from July 1974 to February 1976]. Ljubljana, Slovenia: Slovenska matica.

Parliament of the Republic of Slovenia. 1998. Odnos do preteklosti in narodna sprava: priznanje različnih pogledov kot dejanje za prihodnost Republike Slovenije. Javna razprava [Attitude to the past and national reconciliation-acknowledging different views as an act for the future of the Republic of Slovenia: A public debate]. Ljubljana, Slovenia: Državni zbor.

Parliamentary Gazette of the Republic of Slovenia. 1997a. "A Proposal of an Act Amending the Holidays and Public Holidays Act in the Republic of Slovenia." May 9, 3-4.

. 1997b. "A Proposal of a Resolution on the Unlawful Workings of the Communist Totalitarian Regime.” November 14, 5-6.

. 1997c. "A Proposal of a Law for the Elimination of the Crimes of the Communist Totalitarian Regime.” November 14, 7-15.

. 1997d. "A Proposal of a Declaration on the Unlawful Workings of the Communist

Totalitarian Regime." December 23, 35-6.

Ramet, Sabrina. 2009. The Three Yugoslavias: State-Building and Legitimation, 1918-2004.

Washington, DC: Woodrow Wilson Center Press. 


\section{Vrzgulová, Lutherová \\ Reconciliation: The Institutionalization of Memory in Post-Yugoslav Slovenia}

Repe, Božo. 1988. Mimo odprtih vrat: izbrani dokumenti o dejavnosti okupatorjevih sodelavcev na Slovenskem [Past the open door: The selected documents of the activity of the occupiers' collaborators in the territory of Slovenia]. Ljubljana, Slovenia: Borec.

2002. Jutri je nov dan. Slovenci in razpad Jugoslavije [Tomorrow is a new day: Slovenians and the disintegration of Yugoslavia]. Ljubljana, Slovenia: Modrijan.

. 2009. "Sprava kot kulturni boj” [Reconciliation as a cultural struggle]. In Onstran demokracije. Izjave in stališča Liberalne akademije po letu 2005 [Beyond democracy: Statements and positions of liberal democracy after 2005], edited by Božidar Flajšman, 93-101. Ljubljana, Slovenia: Liberalna akademija.

Ricoeur, Paul. 2004. Memory, History, Forgetting. Chicago and London: University of Chicago Press.

Rotar, Braco. 1994. "Sprava namesto zgodovine" [Reconciliation instead of history]. Razgledi, May 27.

Simić, Olivera, and Zala Volčič, eds. 2013. Transitional Justice and Civil Society in the Balkans. New York: Springer.

Slabe, Janja. 2006. "Narodna sprava v slovenskih časopisih" [National reconciliation in the Slovenian press]. Borec 58 (630-4): 9-60.

Slovenian National Assembly. 1990. "Constitutive Meeting of the Slovenian National Assembly on May 9 1990.” Accessed November 4, 2020. https://exist.sistory.si/exist/apps/parla/ VsiZbor-Seja-001-1990-05-09.xml.

1997a. "Extraordinary Session of the Slovenian National Assembly on January 9 1997." Accessed November 13, 2020. https:/exist.sistory.si/exist/apps/parla/Izredna-01-1997-01-09.xml.

1997b. "Regular Session of the Slovenian National Assembly on July 1, 1997." Accessed November 14, 2020. https://exist.sistory.si/exist/apps/parla/Redna-06-1997-07-01. $\mathrm{xml}$.

1997c. "Extraordinary Session of the Slovenian National Assembly on December 3, 1997." Accessed November 14, 2020. https:/exist.sistory.si/exist/apps/parla/Izredna-16-1997-12-03.xml.

2009a. "Regular Session of the Commission for Petitions, Human Rights and Equal Opportunities on April 6, 2009." Accessed November 15, 2020. https://www.dz-rs.si/wps/ portal/Home/deloDZ/seje/evidenca?mandat=V\&type=magdt\&uid=B4B8DD620C545C5 AC12575A200334BB4.

2009b. "Regular Session of the Board for Domestic Policy, Public Administration, and Justice on June 30, 2009." Accessed November 14, 2020. https://www.dz-rs.si/wps/ portal/Home/deloDZ/seje/evidenca?mandat=V\&type=pmagdt\&uid=540BE61D44EFBE1 CC12575E6003CD9F3.

Study Center for National Reconciliation. n.d. "Education.” Accessed November 15, 2020. https://www.scnr.si/en/education.html.

Tileagă, Christian. 2018. Representing Communism after the Fall: Discourse, Memory, and Historical Redress. Cham, Switzerland: Palgrave Macmillan. 
Toš, Niko et al. 2004. Razumevanje preteklosti. Slovensko javno mnenje 1995-2003 [Understanding the past: Slovene public opinion, 1995-2003]. Ljubljana, Slovenia: Faculty of Social Sciences, University of Ljubljana.

Tucker, Aviezer. 2008. "Historiographic Revision and Revisionism." In Past in the Making: Historical Revisionism in Central Europe after 1989, edited by Michal Kopeček, 1-15. Budapest and New York: CEU Press.

Vodopivec, Peter. 2009. "Politics of History Education in Slovenia and Slovenian History Textbooks Since 1990." In "Transition” and the Politics of History Education in Southeastern Europe, edited by Augusta Dimou, 45-69. Göttingen, Germany: VR Unipress.

Wirsching, Andreas. 2012. Der Preis der Freiheit. Geschichte Europas in unserer Zeit [The price of freedom: History of Europe in our time]. Munich: C. H. Beck.

Zajc, Marko. 2020. “Spomenik Pr'Skelet in Zvezdi: k politiki spomina v Sloveniji v drugem desetletju tretjega tisočletja” [The monument near Pr'Skelet bar and Zvezda cafe: On the politics of memory in Slovenia in the second decade of the third millennium]. Contributions to Contemporary History 60 (1): 152-71.

Zelizer, Barbie. 2008. “Journalism's Memory Work.” In Media and Cultural Memory, edited by Astrid Erll and Ansgar Nünning, 379-87. Berlin and New York: Walter de Gruyter.

Žerovc, Beti. 2020. "Spomenik žrtvam vseh vojn in problematike sodobnega postavljanja javnih skulptur in spomenikov v Sloveniji" [The Monument to the Victims of All Wars and the issues of contemporary public sculptures and monuments in Slovenia]. Contributions to Contemporary History 60 (1): 172-87. 